\title{
Concepts and Methods of Common Property Resource Management
}

\author{
Om Gurung, Ph.D*
}

\section{Capitalist and Socialist Models of Common Property Resource Management}

There are two dominant conceptual models of common property resource management: a capitalist model and a socialist model. The capitalist model argues that resources that are held commonly are subject to degradation. Hence, privatization of public resources is the only viable solution to the problem. The socialist model explains that economic poverty caused by inequitable distribution of resources among rural agrarian population is the driving force of resource destruction. Therefore, collectivization or nationalization of public resources serves as an equitable strategy of resource management. A third model suggested by social scientists, particularly anthropologists, asserts the multiplicity of economic, historical, political, and social dynamics at play in resource degradation. These dynamics have disrupted the local control system which otherwise would serve as effective means of common property resource management. They suggest that the policy makers should recognize, support, and strengthen cultural system and socio-political institutions of local people rather than replacing them with other forms of management strategy, for traditional customs and usages practiced by local people have several positive effects in managing and sustaining common property resources and promoting socioeconomic development.

Common property resources, particularly forests and pastures are rapidly decreasing and deteriorating in developing countries like Nepal resulting in many unintended and unanticipated environmental problems. For many, particularly neoclassical economists, population growth resulting in poverty has exerted pressure on common resources thereby creating what is known as the tragedy of the commons (Hardin 1968). They argue that because of growing population pressure, resources held in common are subject to destruction as individuals maximizes individual gains without bearing the costs. They suggest that the proper solution of the overexploitation of common resources, therefore, is to internalize its costs by making the public aspect of resources private (Runge 1985). With the private property, an individual maximizer will rationally manage resources at its best and highest use and thus remain competitive within the market. They further assume that markets are always best means of allocating public resources and that competition necessarily leads to appropriate management (Vernon 1988).

The socialist model does not accept the population as the principal cause of the tragedy of the commons. It analyzes the increasing rate of population in historical and more socially complex manner than simply invoking aggregate population parameters. For instance, family size reflects rational economic decisions. The cost-benefits ratio of extra-children is high for poor families in poor societies or societies where resources are inequitably distributed, because children contribute economically in agriculture labor or the informal economy of the household at an early age and continue to do so throughout their lives (Hecht 1985). Several community studies from different parts of the world substantiate the assertion of the attribution of high economic values of children in subsistence economies. The socialist model admits that the environmental problems have their

\footnotetext{
* Dr. Gurung is a Reader in Anthropology at the Central Department of Sociology/Anthropology, T. U. Kirtipur
} 
origin in structural poverty among rural agrarian populations. The decision to have extra-children is a rational response to quite concrete economic factors. The point of analysis then, should not focus at the correlation between population and poverty, but rather on historical and political variable that underlie reproductive choice (Hecht 1985). Instead of privatization, public resources should be collectivized or nationalized. It is believed that collectivization or nationalization brings major transformation of social relations as well as basic attitudinal and behavioral changes of the resource users. As a mechanism of equalizing process, collectivization or nationalization could prevent individual maximizers from their over-exploitation of resources.

\section{The Critique of the Capitalist and Socialist Models}

Evidences from both capitalist as well as socialist societies suggest that both models of common property resource management are subject to debate. Both models do not recognize the complexity of local social structures. They try to single out single causal factor: over population by the capitalist model and economic relations by the socialist model. The contrasting views do not seem to address themselves to each other. Both models overlook a variety of interrelations reflected in the resources that are perceived as commons. The privatization model favors only a relative few at the expense of many. It deprives poor people off their public resources, as resources are privately owned by those people who are already privileged and thus have more access to resources. This strategy forces poor people to use the remaining marginal resources that, in turn, accelerate the rate of destruction. It leads to increased inequality in already a system of unequal distribution of wealth (Runge 1985). It also overlooks local cultural system and sociopolitical institutions that are closely associated with resource management. The assumption of market as a regulator of resource distribution and management has already failed in many developing countries like Nepal and India where resource allocation is mediated not by market but by the caste and class position.

The policy of collectivization and nationalization of public resources under state control did not prove practical. Evidences from Eastern Europe indicate that the environmental conditions in socialist countries are emerging as equally damaging as in capitalist countries (Cockburn 1989). Like capitalist countries, the socialist model reduces everything to an economic cause and thereby usually overlooks the multiple causal factors, such as cultural, political, historical, and institutional relations. State ownership and state control of public resources did not necessarily overcome the problem of common property resource management. An exciting example of nationalization of forest resources comes from Nepal. But nationalization of forest resources did not solve the problem of deforestation (Feeny 1990). Deforestation accelerated instead of decelerated, as the nationalization program undermined the local system of management and mitigated obligations of village people to protect their natural resources. Ekvall (1986) and Goldstein (1990) have reported similar situations from Tibet. In the face of worsening conditions, the governments of Nepal and China recreated communal property rights of the local people.

\section{Anthropological Model}

In recent years, social scientists, particularly cultural anthropologists have engaged themselves in analyzing and understanding various cultural strategies adopted by local communities to manage their common resources. Many empirical studies suggest the communal system of management as the best solution to the problem of common property resource management. Their assumption is that people who depend upon natural resources for their survival have always developed certain cultural systems and socio-political institutions to regulate their relations with nature. These cultural systems and socio-political institutions that Julian Steward (1955) refers as the "cultural 
core" are closely related to the subsistence activities and economic arrangements and serve as dynamic adaptive mechanisms to the environment unless they are threatened by external forces.

Anthropologists invariably suggest community forestry as an appropriate and effective solution to the problems of common property resource management in developing countries. Community management strategy is attractive because of the fact that local residents have both the most stake in, and most information about natural resources (Uphoff 1986). However, the success of community management system has achieved its success primarily in small-scale homogeneous society that has stable population and environment. It is less applicable in more diverse ecological conditions and complex as well as heterogeneous society. Therefore, community management system cannot serve as a universal prescription of efficient and equitable resource management (Runge 1985). Therefore, we should analyze and understand a set of interrelated dynamics in broader economic and historical perspective.

Cultural anthropologists and many other social scientists, particularly political scientists and political economists agree that the economic development of a society depends upon the efficient management of natural resources that are perceived as common. They further agree that local institutions can play effective role for resource management. But they differ in their opinions that all social institutions cannot manage and sustain all types of common property resources effectively and equitably. Norman Uphoff (1986) distinguishes five kinds of natural resource management, such as forest management, rangeland management, irrigation water management, watershed management, and soil conservation or cropland management. The management of these resources involves many organizational options. For example, local administration is an appropriate institutional channel where the preferred management practices are quite technical and complex (e. g. watershed and soil conservation management). In the same way, peoples prefer to manage their forest resources by themselves through their community institutions. User groups' association can manage water resources better than others.

Uphoff further illustrates that the management of common property resources depends upon the types of social structure of resource users and the nature of resources to be managed. As stated earlier, community management system is appropriate as well as effective if the resource users constitute an identifiable society. When the resource is more uncertain and the set of users are ill defined, higher level of institutions like elected local government have greater role to play in resource management. For example, user groups can be more effective for irrigation management because users are geographically delimited and resource can be distributed with some precision. Rangeland management, on the other hand, by user groups is less effective because herders have greater mobility to seek alternative grazing sources, and the users for a particular rangeland resource are more difficult to identify. Some high level authoritative decision-making institution is desirable to deal with memberships and resource ambiguities. With the forest management, the resource is geographically fixed and bounded, but the person having access to it are not as limited or limitable as with irrigation water. Users associations are harder to form and maintain on a voluntary basis. An authoritative and inclusive body such as local government becomes more effective in the situation where the resource is more bounded than the set of users (Uphoff 1986).

\section{Effectiveness of Common Property Resource Management}

Common property resource management involves costs and benefits. The cost benefits affect resource management. They vary according to the temporal, spatial, tangibility, and distribution dimensions. The local institutions will be most effective in management if the benefits of Resource management accrue quickly, locally, visibly, and individually or collectively. The 
opposite is true if the benefits are delayed, remote, hard to identify and do not accrue to the investors of efforts.

The management of the natural resources also depends upon the characteristics of resources. The less renewable a resource is the more risk there is that poor management will have drastic consequences, and the more reason one can offer for some form of government involvement. Seasonality is another factor of great importance for resource management. Examples from Botswana, Philippines, Indonesia, and Nepal suggest that the flow of local institutional activity is generally affected by variations in the agricultural season. During wet season, water is abundant and it needs less co-operative efforts for water management and maintenance. As a result, local institutions are less active and united for its management. During the dry seasons, water is scarce, local user groups cannot work effectively and central government's intervention is almost inevitable. Similarly, during the rainy season fodders are abundant in private lands and forest resources need less management attention, while fodders are scarce during the winter resulting in efficient management and distribution of fodder trees among the communities (Acharya 1990).

More importantly, property arrangement is an effective mechanism of resource management. There are numerous examples of communities who preferred to keep and use common property resources jointly. For example, the Rais, Limbu, Sherpa. Chepang, Lapcha, Majhis, Tamangs, Sunuwar, and Danuwar communities of Nepal owned and controlled their natural resources, such as forests and lands jointly and they are distributed in accordance with the family requirements (Regmi, 1971). Because the domestic units held individual rights to use resources not ownership, resource alienation was impossible. This system of property rights protected natural resources from fragmentation resulting in degradation.

More or the less similar practice of property arrangement is reported by Acharya (1990) from the Jirel communities of Nepal. According to him. Jirel own natural resources in different ways such as joint ownership and cooperative ownership. Their property rights depend upon the local perception of resources. Their cognitive categorization of resources, such as ground, fodder tress, non-fodder trees, renewable and non-renewable resources have made them easier to partition forest resources. According to this arrangement, several people own different kinds of resources within the same forest areas. Thus, the ground/lands are owned jointly, but trees are owned individually by number, species, age, and size. Each individual family gets a share of forest resources. Those who do not own animals or graze lesser animals than others receive their proportional share of pasture rent from those who graze animals. Those who do not have ownership rights of forest resources due to non-providing communal obligations or patrilineal inheritance problems or late migration in the village enjoy usufruct rights. Despite existing inequalities in ownership rights, the usufruct rights help Jirel households meet the needs of fodders and fuel-woods. It has also protected and redistributed resources in the community.

\section{Implications of Common Property Resource Management}

Common property arrangements have many social and economic implications. First, it has guaranteed the continuous supplies of natural resources that are essential for subsistence economy of rural people. Second, it has constituted a mechanism of social control to protect common resource. Individual exploitation is kept in check and local resources are protected from destruction by individual beneficiaries. It is not only equitable but is based upon a number of considerations, such as family needs, communal responsibility, respect and welfare (Shrestha 1990). Under this common property arrangement, each individual family can meet their basic needs of timbers, fodders and fuel-woods without destroying or degenerating their resource bases. 
Joint ownership provides checks and balances to prevent over harvestings by illegal means, such as stealing. It also provides incentives and motivates people to protect their forest resources.

Common property arrangement contributes directly to the profitability and sustainability of both agricultural and non-agricultural enterprises. Poor management can have detrimental consequences for rural infrastructure of economic development and health (Uphoff 1986). Common property arrangement has policy implications as well. The diversified and differentiated property arrangements practiced by the local people have several positive effects in managing the use patterns- availability, distribution, and conflicts associated with forest and pasture resources and should be supported and strengthened rather than replaced with a monolithic or exclusively private system of ownership (Acharya 1990). Local system of management should be identified and recognized by the policy makers and planners for the effective and equitable resource management. Local systems of resource management are effective, enduring and productive. They are locally preferred approaches and therefore they should be supported and strengthened. The blueprint approach cannot fit into complex local situations. Planners and policy makers should appreciate the social reality. This is what a social scientist can tell planners and policy makers about the management and maintenance of common property resources.

\section{Conclusion}

To conclude, privatization cannot avert the problems of resource management. People have already experienced effects of privatization of public resources both in developing as well as developed countries. Privatization is not a money plant that could be transplanted anywhere else. International Organizations, such the World Bank and IMF believe that privatization work effectively to advance the economic growth of developing countries. But in everyday experience, privatization has not been working quite successfully even in the most competitive societies of America and West Europe. Under no circumstances, privatization is advisable for developing countries where there are different social, economic, historical, political, and institutional backgrounds.

\section{References}

Acharya, Harihar P., 1990, "Jirel Property Arrangements and Management of Forest and Pasture Resources in Highland Nepal," in Development Anthropology Network, Vol. 7, No. 2 (pp. 16-25).

Cockborn, Alexander, 1989, "Socialist Ecology: What Means It, Why No Other Kind Will Do?" in Opea Street, (pp. 15-21).

Ekvall, Robert B., 1986, Field on the hoof, Illinois: Waveland Press Inc.

Feeny David et. al, 1990, "The Tragedy of the Commons: Twenty Two Years Later," in Human Ecology', Vol. 18, No. 1 (pp. 1-19), Pelunum Co.

Goldstein, Melvyn C. and Cynthia M. Beal, 1990, Nomads of Western Tibet: The Survival of a Way of Life, Berkeley: University of California Press.

Hardin, Garrett, 1968, "The Tragedy of the Commons," in Science, Vol. 126, No. 3859,(pp. 1243-1248), Washington, D.C: American Association on the Advancement of Science.

Hecht. Susanna B., 1985, 'Environment, Development, and Politics: Capital Accumulation and the Livestock Sector in Eastern Amazonia," in World Development, 
Vol. 13, No. 6 (pp. 663-684), Britain: Pergamon Press.

Regmi, Mahesh Chandra,

1971, A Study of Nepali Economic History, New Delhi: Manjushri Publishing House (reprinted).

Runge, C. Forth,

1985, "Common Property and Collective Action in Economic

Development," in Proceedings of the Conference in Common Property Resource Management, Washington, D. C: National Academy Press.

Shrestha, Nanda R., 1990, Landlessness and Migration in Nepal, Boulder: Westview Press.

Steward, Julian,

1955, Theory of Culture Change, Urbana: University of Illinois Press.

Uphoff, Norman T..

1986, Local Institutional Development: An Analytical Sourcebook with Cases, Connecticut: Kumarian Press.

Vernon, Raymond,

1988, The Promise of Privatization, New York: Council on ForeignRelations, 